\title{
Tekstproduktion og vidensproduktion
}

\author{
Bente Kristiansen, Det Humanistiske Fakultet, Københavns Universitet
}

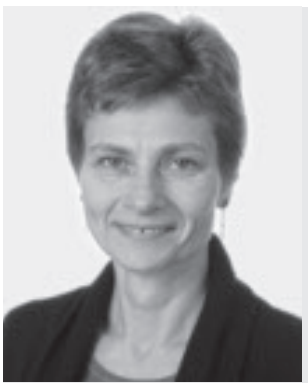

Bente Kristiansen er cand.comm. og ph.d. Som skrivekonsulent ved Det Humanistiske Fakultet, Københavns Universitet, afholder hun workshops for studerende i opgaveskrivning og formidling samt vejleder studerende, der har problemer i forbindelse med opgaveskrivning. Sammen med skrivekonsulent Signe Skov er hun ansvarlig for et projekt under Undervisningsministeriet vedr. udvikling af gymnasieelevers skrive- og studiekompetencer, samt et udviklingsprojekt på Kunsthistorie, KU, om skrivning i fagene. Hun har tidligere været ansvarshavende redaktør for magasinet Humaniora (Forskningsrådet for Kultur og Kommunikation) samt kommunikations- og chefkonsulent i bl.a. Kommunernes Landsforening.

For nogle studerende er det storste problem ved at skrive storre selvstondige opgaver, at de er usikre på hvordan man producerer viden inden for faget. Det viser sig tydeligt i nogle af de tekster, som studerende beder om hjoklp til. Med udgangspunkt $i$ nogle af disse autentiske studentertekster vil jeg her argumentere for, at nogle studerendes problemer med tekstproduktion handler om, at de ikke ved, hvordan faget producerer viden. Jeg angiver, hvordan dette kan forstås ud fra en skrivepadagogisk forstålsesramme - og endelig peger jeg på en skrivepadagogik, der fokuserer mere på kommunikation end på akademiske genrekonventioner.

Mange af de studerende, der opsøger en skrivekonsulent, vil gerne vide, hvad der er galt med deres tekster, hvorfor de ikke er "akademiske" nok - og hvad "det der akademiske« egentlig er. Det lægger jo op til, at man sammenligner teksten med beskrivelser af, hvordan »den akademiske genre« er og så finder 3-5 fejl, som den studerende kan lægge sig på sinde at undgå $i$ fremtiden. Men man kan også vælge at læse teksterne som udtryk for, hvordan de studerende arbejder på at tilegne sig en akademisk arbejds- og tænkemåde inden for deres fag. Og det er denne tilgang, jeg vil udfolde her.

Studerendes problemer med at forstå og tilegne sig universitetets normer er undersøgt og behandlet i forskellige skrivepædagogiske sammenhænge. I grove træk kan man - som Theresa M. Lillis (2001) - skelne mellem to grundlæggende forskellige forståelser inden for skriveforskningen. Den ene ser akademisk skrivning som en færdighed, den anden ser akademisk skrivning som en social praksis (Lillis, 2001: 31).

Hvis man tager udgangspunkt $i$, at skrivning primært er et spørgsmål om skrivetekniske færdigheder, vil den skrivepædagogiske praksis typisk have vægten på det instruktive, ud fra en grundopfattelse af, at de studerende mangler nogle færdigheder i forhold til at mestre genren, og denne mangel søges udbedret gennem instruktion i genrekravene. ${ }^{1}$ Denne tilgang har i praksis potentialet til at hjælpe en hel del studerende til at skrive bedre opgaver og til at klare eksamener.

I denne artikel vil jeg imidlertid pege på nogle svagheder ved primært at lære de studerende nogle genrekrav og på nogle potentialer $\mathrm{i}$ at forstå de studerendes tekster som led i deres arbejde med at indgå i det faglige fællesskab - i et videnskabeligt vidensproducerende fællesskab.

\section{Hvad skriveren fortæller}

Når jeg her vælger at fokusere på akademisk skrivning som en social praksis, har det rod i mine oplevelser som skrivekonsulent på det Humanistiske Fakultet, Københavns Universitet, gennem knapt to år. En del af de problemer studerende præsenterer mig for, dels i kurser, dels i den individuelle vejledning, er tydeligvis problemer med at definere egen identitet ${ }^{2}$ og handlerum inden for sit fag. Nogle studerende siger, at de nok slet ikke hører hjemme på et universitet. Andre har en oplevelse af, at deres sprog og deres måde at ræsonnere på ikke er gangbar på universitetet, men de aner ikke, hvad der så er gangbart. En tredje gruppe er mere udadreagerende og placerer "skylden" på universitet. De karakteriserer den akademiske viden som ubrugelig: „Opgaven ender jo bare på en hylde - ingen gider læse den".

Og så er der alle de tilfælde, hvor de studerende bare gerne vil have hjælp til at skrive mere "akademisk «. De beder om hjælp til genren, men når jeg kigger nærmere på teksterne, ser jeg mange tegn på, at de studerende 
har problemer med at definere deres egen rolle som opgaveskriver inden for faget. Jeg gennemgår her tre eksempler.

I nedenstående tekst udtrykkes f.eks. forvirring med hensyn til, hvilke handlinger skriveren kan foretage sig med henblik på at undersøge opgavens problemstilling:

Opgavens metode vil vare at undersege opgavens hypotese gennem en undersegelse af problemformuleringen $i$ en analyse af serien $x \times x$... Dette gores ved detaljerede noterede observationer af forste afsnit $i$ serien, såvel som af hele fortellingen $i$ de $x x$ afsnit.

Skribenten erklærer her, at vedkommende beskriver en metode, men i realiteten er der ikke tale om nogen metodebeskrivelse, men om en tautologi: Metoden er at undersege gennem en undersegelse i en analyse som gøres ved detaljerede noterede observationer. Skribenten forsøger her at leve op til et krav inden for den akademiske genre om at beskrive undersøgelsesmetoden. (Dette krav har jeg selv ekspliciteret i en workshop, som denne opgaveskriver deltog i). Og beskrivelsen bliver givet med termer, som hører til i den akademiske verden: metode, undersøge, hypotese, undersøgelse, problemformulering, analyse, detaljerede, noterede, observationer. Der er også nogle formuleringer som ofte findes i akademiske tekster, og som alle er med til at skabe afstand mellem skriveren og indholdet. F.eks. sætter skriveren opgaven og ikke jeg'et på subjektets plads: Opgavens metode vil vere. Skriveren bruger også nominaliseringer: Gennem en undersogelse af, $i$ en analyse af. Endelig bruger han verber i passivform: Dette gøres ved. Men skåret ind til benet står der faktisk bare, at han vil notere sine observationer. Og det alene vil næppe blive accepteret som en metodebeskrivelse på noget fag.

Skribenten viser i den efterfølgende tekst, at vedkommende har kendskab til endnu et genrekrav, nemlig at det skal beskrives, hvordan teori og metode sættes $\mathrm{i}$ spil i forhold til et empirisk materiale:

Ved at sammenholde teori med verkobservationer og derigennem udlede en betydning af fremstillingen af $x \times x \times x$ myten $i$ opgaven, mener jeg at kunne finde belog for min påstand (hypotese) gennem analysen af vorket ... Hermed underbygges analysen også samtidig videnskabeligt, da diverse kilder inddrages dertil.

Men skribentens valg af det upræcise verbum »sammenholde« antyder, at han ikke ved, hvordan teori og metode skal fungere i forhold til hinanden. Denne tolkning bekræftes af hans påstand om, at analysen bliver videnskabeligt underbygget ved, at der »inddrages diverse kilder «. Alt i alt tyder skribentens formuleringer på, at han har et kendskab til akademiske genrekrav som f.eks. at der skal være en metodebeskrivelse, og at der skal bruges faglige termer. Men dette genrekend- skab resulterer ikke i en tekst, der forklarer, hvordan et problem er undersøgt på en faglig og videnskabelig måde. Det tolker jeg som udtryk for, at han er usikker på præcis hvilke handlinger, han kan foretage i sin videnskabelige undersøgelse. Med andre ord: Det videnskabelige håndværk, forstået som skribentens muligheder for at undersøge og ræsonnere på en videnskabelig måde, fremstår ikke så klart for skribenten, at han er i stand til at beskrive det $\mathrm{i}$ teksten.

Et andet eksempel er en studerende med flere års praksiserfaring, der nu vil forholde sig kritisk til en forsker, som har været en væsentlig inspirationskilde for hans hidtidige praksis, nemlig Olga Dysthe. I opgaven præsenterer skribenten relevant faglig viden om Dysthes arbejde samt relevant faglig diskussion og kritik af hendes arbejde. Opgaven resulterede da også i en bestået eksamen, men med en væsentlig dårligere karakter end forventet. Forventningerne om en god karakter opstod bl.a. gennem samtaler med vejleder, hvor vejleder gav udtryk for, at den studerende havde god faglig viden og gode faglige refleksioner på et højt niveau. Den studerende havde også lagt et stort - og meget engageret - arbejde i opgaven. Så hvorfor bliver karakteren lav? Mit bud er på grundlag af teksten, at en af grundene er, at skribenten ikke holder fokus på sagen, dvs. på hvad vedkommende undersøger og hvordan, men bringer sin egen erkendelsesproces i fokus:

"Dysthe logger op til flere diskussioner $i$ sit arbejde, men $i$ min afgrensning er det blevet tydeligt for mig, at det er Dysthes forståelse af dialog, som skaber dynamik i min selvrefleksion og erkendelse af en (?) humanistisk videnskabelig position".

Begrundelsen for hvilke aspekter i Dysthes forskning, der skal undersøges, er heller ikke faglig, men personlig:

"Jeg vil $i$ denne opgave ikke diskutere skrivningens betydning for loering, men perifert inddrage skrivningens betydning for den enkelte elevs evne til stilladsering og tillid til egne muligheder, for så langt er Dysthe og jeg enige. Dog ser jeg forhold $i$ det, Dysthe betegner som "Den dialogiske samtale", der krever en narmere diskussion."

Udover at der her argumenteres personligt ("så langt er Dysthe og jeg enige «) og ikke i forhold til sagen, angiver skribenten heller ikke på hvilket teoretisk eller metodisk grundlag, Dysthes begreb om dialogisk samtale vil blive diskuteret. Det, som skribenten faktisk gør i opgaven, er at diskutere Dysthe kritisk ved at analysere hendes egne eksempler på ny ud fra et Bakthin-begreb, som Dysthe ikke selv tager i anvendelse. Men skribenten skriver ikke eksplicit, at han foretager disse akademiske handlinger. I stedet er han eksplicit om sin egen erkendelsesproces. Kort sagt foretager den studerende i hovedtræk de relevante videnskabelige handlinger, men er sig ikke bevidst - udtrykker i hvert fald ikke 
i teksten - at han foretager faglig vidensproduktion.

Et sidste eksempel: Mens nogle studerende sætter deres egen erkendelsesproces (men ikke deres akademiske handlinger) i fokus, går andre studerende $i$ den modsatte grøft og glemmer/camouflerer, at de faktisk har en aktiv rolle $\mathrm{i}$ tekstproduktionen:

Med blandt andre Bruno Latour og aktor-netvoerks teorier, er teknologiens, eller hvad man i denne sammenhoeng kunne betragte som non-human materies, betydning $i$ sociale processer, blevet beskrevet. Selvom Latour har noget andet $i$ tankerne, når han taler om et »Parliament of things" (Latour: never modern), er der dog heller ikke herfra langt til at betragte, hvorledes tojets materialitet interagerer med kroppen og dens relation til verden. Narmere kan vi komme gennem Adrian Mackenzies reformulering af forholdet mellem menneskelig og teknologisk materialitet ... Han er interesseret $i$ at undersøge eventualitet $i$ forhold til teknologi og samtidig forstå teknologi $i$ sin partikularitet.

Denne studerende efterligner en akademisk sprogtone (mange abstraktioner, passivt sprog, få punktummer, indskudte sætninger og komplicerede sætningskonstruktioner etc.). Men han nærmer sig ikke (heller ikke senere i teksten!) en redegørelse for, hvad det er for sammenhænge han ser eller vil undersøge. Teksten kunne give mistanke om, at der er tale om "papegøjesprog« hvor den studerende efterligner (eller plagierer ${ }^{3}$ ) kildetekster uden selvstændigt at tage stilling til stoffet - eller til hvordan en fagligt valid undersøgelse af problemstillingen kan foretages.

Disse tre eksempler på studentertekster er meget forskellige, men de har to væsentlige træk fælles. For det første at skribenterne alle har et kendskab til videnskabelige genrekonventioner. For det andet at ingen af skribenterne udtrykker, hvordan de »handler« fagligt, dvs. hvordan de undersøger en specifik problemstilling på en fagligt forsvarlig måde. Det, der i stedet fremgår af teksterne, er, at skribenterne har problemer med at finde deres egen rolle som skribenter $i$ forhold til universitetet og den faglige viden. Det er også dette problem, der afspejles i det gentagne spørgsmål fra studerende: Må jeg bruge »jeg « $i$ min opgave? Når det spørgsmål overhovedet melder sig, er det jo fordi, skribenten ikke er klar over, at det er fuldt legalt at foretage en række videnskabelige handlinger, f.eks. at træffe en række valg vedrørende empirisk materiale, teoretisk grundlag, analyse- eller undersøgelsesmetode - samt den egentlige undersøgelse, analyse og tolkning. Det, jeg ser i disse tekster, er kort sagt en usikkerhed med hensyn til, hvordan de skal agere i det faglige fællesskab. Men hvorfor kan det være så svært for studerende at lære universitetets akademiske normer for, hvordan man forholder sig til viden?

\section{Den studerende i det faglige fællesskab}

Jeg møder mange studerende, der har stor ærefrygt for den viden, universitetet repræsenterer, og de føler sig faktisk som tomme kar, der skal fyldes op med viden fra universitetets guldgruber. De er ikke klar over, at de forventes at forholde sig til universitetets vidensproduktion, at orientere sig i eksisterende forståelser inden for faget, at skabe sig et rimeligt overblik over metoder og blive $i$ stand til at argumentere for egne analyser, egne undersøgelser og i sidste ende: Egen vidensproduktion inden for fagets rammer.

Faktuel viden og beherskelse af teoretiske områder er væsentlige indhold i en del universitetsopgaver, men f.eks. bachelor-opgaver og specialer er selvstændige opgaver, hvor man forventer, de studerende demonstrerer, at de behersker et videnskabeligt håndværk $\mathrm{i}$ form af at kunne undersøge et fagligt problem med baggrund i relevante teorier og metoder. Denne bevægelse op i taksonomierne er fremmed for nogle studerende. Ikke nødvendigvis på grund af manglende kognitive kompetencer eller manglende studiekompetencer, men muligvis på grund af en usikkerhed over for at påtage sig rollen som vidensproducent. Det er et stort identitetsspring at gå fra at være den dygtige "videnstilegner» til den kritiske og kreative vidensproducent. Og nogle studerende er slet ikke klar over, at de faktisk selv producerer ny viden, når de f.eks. anvender teorier og metoder $\mathrm{i}$ forhold til et empirisk materiale.

På Specialebloggen ${ }^{4}$, hvor studerende fra hele landet blogger om specialeskrivning, skriver en studerende f.eks. om sine problemer netop med at komme fra at læse (tilegne sig viden) og til at producere viden (gå i gang med analyserne):

... jeg kommer hurtigt til at sidde og springe rundt $i$ bogerne og laese lidt rundt omkring ... og når jeg så skal skrive noget ned fra en bog, bliver det til korte brudstykker, der ikke rigtigt kan bruges til noget ... Jeg overvejer at ga $i$ gang med mine analyser... men det er også lidt svaert at gå i gang med dem, når man ikke har loest den teoril metoder, man skal analysere på baggrund af...5

I disse tilfælde bliver den studerende ikke hjulpet meget af overordnede instruktioner om, hvad der bør stå i opgavens forskellige afsnit. Den studerendes problem er mere grundlæggende: Hvad gør jeg med al den viden $i$ alle de bøger og artikler? Hvordan arbejder jeg med den? Hvordan bruger jeg teorier og metoder i min egen undersøgelse? Hvornår kan jeg stå frem i teksten med mine egne vurderinger? Hvordan argumenterer jeg tilstrækkeligt videnskabeligt for det, jeg mener, jeg har fundet ud af? De mangler kort sagt en klar og brugbar viden om, hvad der accepteres som gyldig viden inden for faget.

Det er måske ikke så underligt. For universitetets opfattelse af, hvad videnskabelig viden er, er ikke er en statisk størrelse. Hverken over tid eller fra fag til 
fag. Theresa Lillis har sammen med Joan Turner (2001) givet et bud på, hvordan den aktuelle akademiske praksis bør ses $i$ en bredere historisk og epistemologisk ramme for at forstå, hvad der er på spil i de studerendes skrivning og for at kunne give bud på en meningsfuld pædagogisk praksis. Lillis og Turner peger på, at der er sammenhæng mellem den måde, vi udtrykker os på, og den måde, viden konstrueres på. De henviser til studier inden for videnssociologien, mere specifikt til Charles Bazermanns undersøgelse (Bazermann 1988) af, hvordan Newton udviklede nye retoriske former for at kunne overbevise om sine kontroversielle opdagelser. Newton blev her foregangsmand for en ny videnskabelig genre præget af en stram struktur, af logisk sammenhæng og af imødegåelse af modargumenter.

Lillis og Turners pointe er, at akademiske genrer hænger sammen med aktuelle socio-kulturelle forhold, og at det derfor er et problem, når akademiske genrer beskrives som om, de er uafhængige af tid og sted. Newtons skrivestil fremhæver f.eks. universalitet, sikkerhed, rationalitet og epistemisk klarhed, men netop disse værdier sættes kraftigt til debat i de aktuelle videnskabelige debatter i en postmoderne verden. Lillis og Turner har foretaget empiriske studier, der viser, hvordan en generel akademisk handling som f.eks. at definere begreber antager meget forskellige former inden for forskellige fag (Lillis og Turner 2001: 61). ${ }^{6}$

Problemet, som Lillis og Turner ser det, er ikke forskelligheden men den manglende synliggørelse af forskelligheden, fordi man på den måde - ureflekteret og usynligt - viderefører bestemte måder at beskrive og konstruere viden på. Lillis og Turner mener derfor, at det er nødvendigt at gøre sproget synligt - at forholde sig til sammenhængen mellem det sproglige, retoriske udtryk og de bagvedliggende værdier og forståelser af, hvad der er viden. Ikke mindst det bredere optag til universitetet gør det nødvendigt at være eksplicit omkring denne sammenhæng mellem vidensidealer og sproglige udtryk. For som Lillis og Turner peger på, er der en modsætning mellem at optage bredt og samtidig tage en bestemt udtryksform, genre, for givet. Deres »løsning« er derfor at være eksplicit omkring akademiske genrekonventioners sammenhæng med aktuelle kulturelle forhold, heriblandt videnskabsteoretiske forståelser. ${ }^{7}$

\section{Skrivepædagogisk praksis}

Denne indsigt i sammenhængen mellem vidensidealer og genrekrav prøver jeg at bruge i praksis i min undervisning og i min vejledning. Jeg forklarer de studerende at det, de forventes at foretage sig på universitetet er at producere viden. Og det gør man ved at bygge videre på andres viden (og fortælle hvor man har den viden fra!). Og hvordan man helt præcist gør, dvs. hvad der helt præcist skal til for at denne viden opfattes som gyldig viden, afhænger af faget (og af de videnskabs- teoretiske positioner). Men at det under alle omstændigheder er vigtigt, at man lægger processen bag ens vidensproduktion frem. Alle mellemregningerne skal med, sådan at alle vi andre i det faglige fællesskab får mulighed for at diskutere styrker og svagheder i produktionsprocessen. Jeg lægger altså for det første vægt på, at den studerende foretager en række handlinger, dvs. er aktiv - ikke reproducerende, men producerende. For det andet pointerer jeg, at den studerende indgår $i$ et fagligt fællesskab, hvor vidensproduktionen skal diskuteres. Lige præcis det med det faglige fællesskab kan dog være en smule vanskeligt at gøre begribeligt $i$ et meget individualiseret universitetsmiljø. Jeg prøver derfor ihærdigt at skabe muligheder for gruppediskussioner og feedbackgrupper.

Når jeg lægger vægt på kommunikation frem for genrekrav, betragter jeg også de studerendes tekster som kommunikative udtryk. I vejledningssituationerne tilstræber jeg derfor, at teksterne bliver omdrejningspunktet for en samtale om, hvordan den studerende foretager sin faglige undersøgelse - og om hvordan det kan kommunikeres i teksten, så læseren forstår det. Helt konkret betyder det, at jeg stiller de spørgsmål til den studerende, som teksten rejser hos mig, når jeg læser den. Jeg ekspliciterer min læseroplevelse og spørger f.eks.: "Hvad mener du her? Hvordan hænger denne oplysning sammen med den næste? Hvorfor fortæller du mig dette her? Dette her gør mig rigtig nysgerrig hvad mere kan du fortælle om det? Hvor ved du dette fra? Hvad ligger der i dette begreb? « Jeg prøver altså at gøre skribenten opmærksom på, hvordan jeg som læser forstår - og ikke forstår - teksten ${ }^{8}$. Det giver både den studerende mulighed for at se sin tekst udfoldet som en dialog og for at komme videre $i$ en erkendelsesproces gennem det at skulle uddybe og præcisere. Jeg prøver at undgå at give vurderinger af teksten, men giver gerne konkrete forslag til omformuleringer: »Nåh ... hvis det er det, du mener, kunne du måske bytte rundt på de to oplysninger - eller kæde den sætning sammen med den sætning med et "men" ... « I sådan en dialog skal den studerende jo helst gå med og afprøve alternative formuleringer.

Derved făr vejledningen dels fokus på, hvad den studerende GØR, dels på hvordan det kan KOMMUNIKERES. Det bringer kommunikationen i fokus, og ideelt set udvikler den studerende ikke bare bevidsthed om, hvordan faget validerer viden, men også kompetencer til at kommunikere det.

En af fordelene ved at arbejde med akademisk skrivning som en social praksis frem for som en særlig genre er, at de studerende (ideelt set) udvikler kommunikative kompetencer, og disse kommunikative kompetencer rækker videre end universitetet. Som akademiker i et videnssamfund skal man arbejde med vidensproduktion i mange forskellige sammenhænge. Og hvad der er gangbar og valid viden $i$ en specifik faglig sammenhæng udtrykt $i$ en form, som overbeviser $i$ et specifikt 
fagligt fællesskab, er ikke nødvendigvis gangbart og validt $i$ andre fællesskaber. Men akademikere har brug for at kunne kommunikere og vidensudvikle i mange forskellige og foranderlige fællesskaber.

\section{Referencer}

Ask, Sofia (2007). Vägar till ett akademiskt skriftspråk.Växjö University Press, 2007. (Acta Wexionensia. Humaniora, 115).

Bazerman, Charles (1988). Shaping Written Knowledge:The Genre and Activity of the Experimental Article in Science, Madison, Wisconsin: University of Wisconsin Press.

Elbow, Peter (1988). Writing with Power. Techniques for Mastering the Writing Process. (1981) Oxford: Oxford University Press, Inc.

Ivanic, Roz (1998). Writing and Identity. The Discoursal Construction of Identity in Academic Writing. Amsterdam/Philadelphia: John Benjamins publishing company.

Knudsen, Sanne (2009). Har du et problem? I: Dansk Universitetspadagogisk Tidsskrift nr.7.

Lea, Mary R. (2004): Academic literacies: a pedagogy for course design in: Studies in Higher Education, Vol 29, no 6, December 2004

Lea, Mary R and Street, Brian V. (1998). Student Writing in Higher Education:An Academic litteracies Approach in: Studies in Higher Education, 23.2.157-172.

Lillis, Theresa M. (2001). Student Writing. Access, Regulation, Desire. London and New York: Routledge, Taylor \& Francis Group.

Lillis, Theresa, M. and Turner, Joan (2001). Student Writing in Higher Education: contemporary confusion, traditional concerns in: Teaching in Higher Education, Vol. 6, No. 1, 2001.

\section{Noter}

1 Lea og Street (1998) beskriver, hvordan de skrivepædagogiske tilgange kan ses som tre forståelser, der udspringer af hinanden. Fra den færdighedsorienterede tilgang udsprang en tilgang med fokus på »akademisk socialisering", hvor den pædagogiske indsats ikke kun handler om konkret genrekendskab men også er orienteret mod at få de studerende til at forstå den akademiske kultur, dens læringsmål etc. Den tredie forståelse er teoretisk funderet i »New Literacy Studies" og fokuserer på, hvordan læse- og skrivefærdigheder er integreret $\mathrm{i}$ institutionelle forhold, magtforhold, kommunikative praksisser, identitetsskabelser etc.
2 Ivanic (1998) har beskrevet, hvordan skrivning kan forstås som en kompleks identitetsdannelsesproces. Her anvender jeg dog udelukkende begrebet identitet som betegnelse for den studerendes opfattelse af, hvad man gør inden for sit fag.

3 Megen forskning inden for plagiering peger netop på, at mange studerende plagierer ubevidst - de forsøger at finde den rette jargon, se f.eks. Ivanic, (1998), Lea og Street (1998) og Ask (2007).

4 Specialebloggen er oprettet af og administreres af skrivekonsulent Signe Skov, KU. Bloggen findes på http://studieportal. hum.ku.dk/studievejledning/skrivehjaelp/specialebloggen/

5 Lea og Street (1998) beskriver tilsvarende fra deres interview med studerende, hvordan studerende har svært ved at se, hvordan de som uvidende studerende kan skrive noget som helst andet end, hvad autoriteterne på området har skrevet: "I don't know anything about the subject other than what I've read in books so how on earth could I write anything which was not someone else's idea?" (Lea og Street, 1998: 167).

6 Sanne Knudsen (2009) påpeger, at der er stor forskel mellem den hverdagsbetydning, som ligger i disse begreber, og de forskellige faglige betydninger, som de samme begreber har i forskellige fag.

7 Lea opregner tolv principper for undervisning baseret på »academic literacies" tilgangen (Lea, 2004: 744). Et af principperne er netop at anerkende sammenhængen mellem epistemologi og vidensproduktion. Et andet er ikke at skabe en dikotomi mellem akademisk skrivning (literacy) og andre skrivninger (literacies). Lea beskriver detaljeret et undervisningsforløb baseret på disse principper.

8 Der er her tale om, hvad Peter Elbow (1988) betegner som læserbaseret feedback, dvs. eksplicitering af læseroplevelser. Jeg har ikke forudsæetninger for at give, hvad Elbow kalder kriteriebaseret feedback, dvs. feedback baseret på fagets kriterier. Men på den anden side er jeg i disse situationer - ligesom med-studerende - en akademisk læser, der har forventninger om faglig argumentation og validering af viden. Dermed bliver den læserbaserede feedback ofte også en feedback, der fokuserer på en kritisk-analytisk tilgang. 